\title{
Bakos Áron
}

\section{Fogyasztás, liminalitás, puerilizmus: egy sokrésztvevoós online szerepjáték használatáról}

\begin{abstract}
Absztrakt
A dolgozat a World of Warcraft címú program jellemzóit elemzi elsôsorban Huizinga játék-, Bauman liquid modernity és Szakolczai permanent liminality fogalmán keresztül. A tanulmány a programot a játék fogalmának kritikai olvasatával, az online és offline világok dichotómiáját meghaladva, az elméleti keret által kijelölt, tágabb szociokulturális kontextuson belül helyezi el. A program használatával kapcsolatban bizonyos fogyasztási gyakorlatokat, az identitás- és csoportképzés folyamatát, ezek egyes jellemzőit mint a társadalom tágabb és a program szúkebb közegére egyaránt érvényes, a játék esetében mint a puerilizmus fogalmán keresztül leírható jellemvonást azonosít.

\section{Szerzô}

Bakos Áron (1988) doktorandusz a Babeș-Bolyai Tudományegyetemen, múzeológus a Néprajzi Múzeumnál. Érdeklődési területe a történetmondás antropológiája, a liminalitás, a játék, valamint a kulturális antropológia története és módszertana.

Email: bakosaron@gmail.com
\end{abstract}

https://doi.org/10.31176/apertura.2019.14.2.5 


\section{Bakos Áron}

\section{Fogyasztás, liminalitás, puerilizmus: egy sokrésztvevôs online szerepjáték használatáról}

A videojátékok használatának vélt vagy valós következményei a közbeszéd egyik kedvelt témáját képzik. A sokszor a tudományos szövegekben is visszhangra találó érveket akár így is összegezhetjük: az esélydiskurzus fô megállapítása, hogy játék, tehát jó; a veszélydiskurzus ezzel szemben azt állítja, hogy virtuális, tehát rossz. A gyerekkor nosztalgiája, a kötetlenség, a kísérletezés, a fantázia egyfelôl; a jelen leáldozása, a tartalmatlanság, az üresség, az értékvesztés másfelôl. A következôkben a - sarkítottan összegzett - diskurzus két alaptételét szeretném megkérdôjelezni: a játék valójában nem játék, a virtuális nem a valós ellentéte.

Kevésbé darabosan fogalmazva a tanulmányban két feladatra vállalkozom. Egyrészt egy sokrésztvevôs online szerepjáték kapcsán a játék fogalmának alkalmazhatóságát vizsgálom. A kiindulási problémám, hogy a kutatók bár sokféle módon, jelzôs szerkezetekbe sûríthetô módon beszélnek - például addiktív (Taneli-Guo-Mushtaq 2015), gazdaságilag káros (Potter 2015: 294-298.) vagy álvalóságot építô (Dreyfus 2009: 97-99.) - játékokról, de a fogalom alkalmazhatóságát nem kérdójelezik meg. Másrészt, szemben az egyre határozottabb módszertani ajánlásokkal (vö. Hine 2015), még ma is jellemzô, hogy a virtuális és a valós közeget elválasztva, sôt, sok esetben egymással szembeállítva írják le. A következókben a program társas világát ezért nem önmagában, hanem egy tágabb társadalmi, kulturális közeg részeként mutatom be. A játék fogalmát Huizinga klasszikus meghatározása alapján, a tágabb kontextust pedig a baumani liquid modernity [folyékony modernitás] ${ }^{[1]}$ és a permanens liminalitás leírása alapján vázolom fel. Ebben a keretrendszerben próbálom levezetni, hogy a számítógépes programok hogyan válnak a játék helyett a puerilizmus terévé, és ezzel szoros összefüggésben azt a folyamatot, melynek során a virtuális közeg a materiális kötöttségektôl megszabadított liminális fogyasztói térré válik. A két megközelítésmód egymásra olvasása természetesen csak a program egyik lehetséges értelmezési módját rajzolja ki. A dolgozat empirikus alapját néprajzi kutatásom képzi, mely a World of Warcraft, egy sokrésztvevős online szerepjáték közegében kialakult, föleg budapesti és környékbeli fiatal felnôttekből álló csoport vizsgálatát célozta. [2]

A tárgyalás kiindulópontja tehát Huizinga klasszikus játékdefiníciója. A meghatározás szerint „a játék szabad cselekvés vagy foglalkozás, amely bizonyos önkéntesen, elôre meghatározott idôben és térben, szabadon választott, de föltétlen kötelezô szabályok szerint folyik le; célja önmagában van, bizonyos feszültség és öröm érzése, továbbá a »közönséges élet«-tôl való »különbözôség « tudata kíséri” (Huizinga 1944: 37). A kérdésünk az, hogy mindez hogyan vonatkoztató a World of Warcraft használatára. Megválaszolásához a következôkben a program köré szervezôdô csoport 
domináns gyakorlataival vetem össze a meghatározás egyes pontjait.

A ,játékba” történô belépés, a program használatának megkezdése, ahogy abbahagyása és felfüggesztése is, természetesen szabad cselekvés. A belépés után, a használati idôtôl, a befektetett idôtôl, a közegben felgyúlt kapcsolati tôkétôl függően a megszakítás lehetôsége azonban egyre több korlátba ütközik, vagyis az egyén számára egyre több potenciális veszteséggel jár. Ezek a korlátok természetesen nem tiltásokként, formálisan jelentkeznek, hanem fóleg a befektetések elvesztésének racionális gátjából. A játék tartós és rendszeres használatára tehát a legtöbb esetben tévedés addikcióként, a „valóssal” szemben a „virtuális” irracionális választásaként tekintenünk, legalábbis amennyiben az addikciót mint irracionális cselekedetet azonosítjuk. A program közegében ugyanis az egyének javakat termelnek meg, immateriális tárgyakat hoznak létre, vagyonelemekre tesznek szert, kapcsolatokat alakítanak ki, különbözô ismereteket szereznek, tehát különbözô tôketípusokra tesznek szert. Ám ezek az erôforrások javában a program világába vannak zárva, tehát a kilépés ezek szinte teljes elvesztését, használhatatlanságát vonná maga után. A használat tehát egy zárt társas rendszerben zajlik, ami a párhuzamos jelentéseit és tôketípusait kitermelve csak korlátozottan konvertálható a közegen kívüli elemekre. Ezt figyelembe véve tehát félrevezetổ lehet, ha a tartós használatot mint irracionális függôséget és nem mint e javakhoz, tôketípusokhoz való racionális ragaszkodást azonosítjuk. Ugyanakkor e ponton tehát a kilépés lehetôsége, a használat szabadsága egyértelmúen sérül, mert az egyénre ugyanolyan társas kényszerek nehezednek, ahogy bármilyen más, offline szerveződô társas közegben. A Huizinga által meghúzott választóvonal valóság és komolyság, a játék elkülönült és a mindennapok világa között tehát transzparenssé válik. Ahogy azonban e közegekkel szemben sosem tekintjük a tartós elkötelezôdést egyéni, pszichológiai vagy morális gyengeségnek, úgy ez a hasonló programok esetében sem tûnik indokoltnak. Mindenesetre, ami a huizingai játékdefiníciót érinti, a használat szabadságával kapcsolatban erôs kételyeket fogalmazhatunk meg.

Az előre meghatározott tér és idô kitétele is csak részben teljesül a program domináns használati módjának tekintetében. A játékosok cselekedetei ugyanis csak részben egyéniek, illetve a program úgy van megalkotva, hogy a központi jelentôségú elôrejutás (progress) érdekében a felhasználóknak már viszonylag korán közös, összehangolt cselekményeket kell végrehajtaniuk. Ezek koordinálására formálisan is létezố csoportokat, úgynevezett céheket (guild) ${ }^{[3]}$ hozhatnak létre, amely saját kutatásom esetében azt jelentette, hogy hetente két vagy három alkalommal, meghatározott idôben részt kellett venni e közös, egyéni feladatokra és felelősségi körökre osztott, formálisan kinevezett vezetốk által koordinált cselekményekben. Ezen kötelesség elmulasztása formális és informális szankciókkal jár, hosszabb távon a csoporton belüli marginalizálódást vagy kirekesztést vonja maga után. A belépés önkéntességének részleges feladásával a szabadság e társas kényszerek mentén sérül, míg a definícióból következô, az elôre meghatározott térre és idôre vonatkozó kritérium teljesül. Ez csak azonban a közös cselekvésekre igaz, máskülönben az általam megismert felhasználók általában napi szinten, a hétköznapok részeként, rendszeresen használták a programot. Erre még az elkülönülés kapcsán késóbb részletesen visszatérek.

A következô pont, a kötelezô szabályok kérdése, a program esetében elsô ránézésre teljesül. 
Ugyanakkor ezek a szabályok változnak: ahogy új kiegészítôk (eleddig nem kevesebb, mint hét darab), frissítések jelennek meg, az egyes képességek, tárgyak, szereplôk értéke, hasznossága, a cselekményeknek értelmet adó kontextus részlegesen, de egyes esetekben egészen radikálisan megváltozik. Tehát a szabályok zártságára és kötelezô érvényére vonatkozó kitétel - amelynek Huizinga megközelítésében az az értelme, hogy „rendet teremt, sôt maga a Rend” (Huizinga 1944: 19) - így szintén csak részlegesen teljesül. Az új szabályok ugyanis a felhasználókat sok esetben rosszul érintik, a módosult elốrások megtanulása, az alkalmazkodás képtelensége a relatív másokhoz, jellemzően a szúkebb csoport tagjaihoz mért - teljesítmény visszaesésével jár, a közös feladatok végrehajtásában betöltendô szerepnek való megfelelés kudarcához, s végül a csoporton belüli marginalizációhoz vezet.

A közegben megfogalmazott célok tehát nem önmagukban állnak, a legtöbb esetben valamilyen konkrétan megszerezhetô tárgyra, elnyerhetố képességre, felmutatható teljesítményre (achievement ) irányulnak. A játék közege számszerúen kimutatható és összemérhetô teljesítményeket rajzol fel, amely a versenynek, a sikeresség összemérhetô közegének ágyaz meg. S noha a létrejövő csoporton belül felfedezhetjük egymás segítésének, az önzetlenségnek a mozzanatait, de e látszólag altruista cselekedetek az ajándékozás irányával, szereplóivel, kötelékeivel, körével sok esetben hatalmi viszonyokat, hierarchiákat jelölnek ki, tesznek a pontozáshoz mérten elvontabb szinten világossá (vö. Mauss 1966). Valójában a csoport nagyon sok esetben a relatív teljesítmények összemérésének közege, a legfontosabb tulajdonság, a játékon belüli jártasság felmutatásának eszköze. A részvétel tehát a domináns és tartós használat során nem önmagára, hanem a csoportra, az eredményekre, a teljesítményre és a versenyben való helytállásra, a csoport számára való értékesség felmutatására irányul.

A tér és idô kérdésével kapcsolatban fentebb már jeleztem, hogy a hétköznapokkal szembeni elkülönülés kritériuma nem teljesül. Felmerülhet a gyanú, hogy valójában ezen elv csak valamifajta radikális, addiktív használati mód során sérül. Ám a kutatásom során úgy találtam, hogy a napi szintú belépés és használat fedi le a domináns használati módot, amelyet maga a program is támogat már önmagában azzal is, hogy folyamatosan fut, folyamatosak a történések. A hétköznapi elköteleződés rendszerét még olyan jegyek támogatják, mint a napi küldetések rendszere, amelyek folyamatosan új célokat, újonnan felmutatható teljesítményeket jelölnek ki, vagy az, hogy a program kommunikációs felületté, kapcsolattartási fórummá válik. 
Az érzelmek szintjét utoljára hagytam, hiszen társadalomtudományi megközelítésben az egyéni, szubjektív érzésvilág kevésbé hozzáférhetô. Mindenesetre annyi bizonyos, hogy a beszélgetések során, éppen a napi küldetésekkel kapcsolatban az adatközlők gyakran panaszkodtak a monotonitásra és az unalomra. A jelenség elterjedtségét jelzi, hogy a hasonló repetitív, unalmas feladatokra külön szót használnak a közegben (grinding), kiváltásukra pedig a bérmunka, a kiszervezés (a program közegén belül előállított javak cseréje a program közegén kívül előállított javakra) vagy az automatizálás (úgynevezett botolás, azaz a repetitív cselekmények felhasználói beavatkozástól független végrehajtása programok segítségével), a szabályokkal szembemenô módját is alkalmazzák (vö. Paoli 2013).

Mindent összevetve, e nagyon vázlatos áttekintés alapján is világos lehet számunkra, hogy a játék klasszikus, Huizinga által adott meghatározása alapján a programot, pontosabban a program domináns használati módját indokolatlan játéknak neveznünk. Korábban elsôsorban ez a felismerés vezetett ahhoz, hogy az egyetlen, fentebb nem tárgyalt jelenségkört, amelyet a köznyelvi terminust átemelve trollkodásnak és még esetleg bolondozásnak nevezhetünk, mint játékos jelenséget helyezzem el (Bakos 2016). Tanulmányomban a trollkodás értelmezésébe bevont bergsoni nevetésfelfogás vagy a bahtyini karneválértelmezés egyaránt afelé mutatott, hogy a programot a játékkal szemben a komolysággal és munkával azonosítsam (vö. Huizinga 1944: 17), és a trollkodásra és más rokon jelenségekre mint inkább ennek feloldási kísérletére tekintsek.

A korábban részletesen kibontott elképzelésemet alátámaszthatja, ha értelmezésünkbe bevonjuk Victor Turner egyik késóbbi fogalmát, amelyet a posztmodern jelenségek értelmezésére dolgozott ki. Eszerint a liminálissal szemben megkülönböztethetjük a státuszváltás elemét nélkülözô, de a folyamatosságot, a hétköznapiságot, az egyént mindennapos múködéséből kizökkentô, sokszor egyfajta egzisztenciális megrendüléshez vezetô liminoid élményeket (Turner 1974). Ebben az értelmezési keretben helyezhetjük el a trollkodás jelenségét, szembeállítva azt a program mindennaposságával. Mindezzel megmagyarázhatjuk, hogy a program miért nem képes a játékokra egyébként jellemzô, a communitas illékony, örömteli élményét közvetíteni (Turner 2012), hiszen ebben a dichotómikus rendszerben a program egyértelmúen a struktúrát képviseli és teremti meg a communitas állapotával szemben.

A munka és a játék, a játék és a komolyság, a struktúra és a liminalitás, a hétköznapiság és a karnevalitás, valamint az ismétlés és a kizökkenés szembeállításra épülô modellt ma részben félrevezetônek találom. A felvázolt rendszerben ugyanis a trollkodás megértéséhez a fenti modellek alkalmazása mindenképpen egy dichotómia felállítását kívánta meg. Ha a trollkodást a liminoid, a hétköznapitól eltérô, a gépies monotonitást megtörô és egyes viselkedéseket kifigurázó, kigúnyoló és büntetô cselekményként értelmezzük, akkor ennek a cselekvésnek egy strukturált, mindennapos, monoton közegbe kell ágyazódnia. Másképpen, a communitas és a liminoid, a karnevál, a nevetés mind feltételezik egy stabil struktúra meglétét, ezek a fogalmak, ez az értelmezési keret ezzel szemben nyeri el értelmét. Vagyis a programot mint ennek a struktúrának kifejezôdését, létrehozó közegét azonosítjuk, és ezzel elvitatjuk játék jellegét, és az ott zajló 
tevékenységeket a kötelezettségek, a társas kényszerek és a monotonitásra is utaló, munka jellegú tevékenységként azonosítjuk. Bár ezt részben ma is plauzibilisnek tartom, de ennek ellenére azt hiszem, hogy a modell mégsem tökéletes. Ugyanis abban az esetben írná le pontosan a valóságot, ha egyértelmúen azt tudnánk mondani, hogy a program használata munka, hétköznapi és komoly cselekedet. Ez azonban nem pontosan fedi azokat a gyakorlatokat, amelyeket az általam megismert személyek folytatnak, és azt a szubjektív érzést sem, ahogy saját tapasztalataikat interpretálják. A program ugyanis - ahogy azt fentebb röviden megpróbáltam kifejteni - valóban sok szempontból nem felel meg a játék ezen kritériumainak, de minden esetben felidézi ezeket a jegyeket, a programot ezeknek a jegyeknek az ígérete lengi körül, a felhasználók körében ennek megfelelôen megjelennek ezirányú várakozások, és e várakozások mentén a tapasztalataiknak és csalódottságuknak ez irányba mutató beszámolója.

Mindezek alapján úgy gondolom, hogy a mélyebb megértést nem segíti elô, ha a munka és a játék dichotómiájára épító értelmezési keretben maradunk. A fenti gondolatmenet, ahogy e két fogalompár is, jellegzetesen modern dichotómiákon nyugszik (vö. Clayre 1974). A játék és a munka szembeállítása olyan, a modernitásban magától értetôdônek tûnô szembeállításokon nyugszik, mint a termelés és a fogyasztás helye, a nyilvános és a magánszféra, a munka- és a szabadidô, a komolyság és a szórakozás. A modernitásban az állam tulajdonképpen ezek szétválasztását garantálta, az egyén méltósága és szabadsága részben ezek különállásán nyugodott. Bauman ugyanakkor éppen arra mutat rá, hogy az állam ezt a szerepét mára feladta, legitimációs forrását a védelem helyett, a büntetésben találta meg (Wacquant 2009), és a korábbi stabil keretek, az elválasztásokon és szembeállításokon nyugvó keretrendszer - a stabilitást, a kötöttségeket és kötôdéseket felszámoló - liquid modernity fázisában eltúnik (Bauman 2000).

A következőkben - a korábbi értelmezési kerettel szemben, mely a felhasználók csoportját némileg elzártként, egyfajta egzotikus online törzsként ábrázolta (vö. Baym 2006: 41-47.) - olyan megközelítésmódot követek, mely a kortárs kulturális és társadalmi rendszer kontextusában értelmezi a program használatát. A játék fogalmának alkalmazási korlátai a fenti megközelítésben azt sejtették, hogy a program használata körül egy olyan sajátos, elzárt kulturális közeg jön létre, amelyben ez a fogalom csak megszorításokkal alkalmazható. A következókben ezzel szemben amellett érvelek, hogy a program használatának értelmezését sokkal pontosabbá teszi, ha nem elszigetelt vagy teljesen önálló jelenségként, hanem napjaink kulturális és társadalmi rendszerének részeként tekintünk rá. Jellemvonását tehát nem a fenti dichotómiákból, hanem e rendszer természetéból próbáljuk levezetni.

Vizsgálódásaink során induljunk ki abból a metaforából, amelynek segítségével Bauman a premodern, a modern és a liquid modernity viszonyát próbálja megragadni, s a három korszakot az erdész, a kertész és a vadász képén keresztül írja le (Bauman 2000: 98-100., vö. Bauman 1991: 26-28.). Mindegyik szereplố a világban elfoglalt helyünk, a világhoz, a természethez, a dolgokhoz való viszonyulásunk más-más módját, az értékek és felelôsségek más-más felfogását képviseli. Ha a metaforát kibontjuk, akkor a liquid modernity fázisára jellemző fogyasztás excentrikusságában a vadászat intenzitásához, tárgyában az aktuálisan mindig változó prédához, a környezet felélésében 
a pusztításhoz, kapcsolatainak törékenységében a portyázó csapatok alkalomszerúségéhez hasonlítható. Bauman szerint azonban e folyamatban tulajdonképpen nem a zsákmány birtokbavétele, hanem felhajtása válik fontosabbá. Vagyis ha egy olyan folyamatot képzelünk el, amely a vágy felébredésétôl a vágy tárgyának kielégítéséig ível, akkor Bauman szerint a liquid modernity korszakában a középsô szakasz kerül elôtérbe. Másképpen, ha a premodernben a vágyak születése, a modernben a vágyak beteljesítése, akkor a liquid modernityben a vágyak fenntartása válik központi egzisztenciális kérdéssé (vö. Bauman 2007: 98).

Mindez jól rímel Baudrillard diagnózisára, aki szerint a tartalom iránti közömbösség, a puszta operativitás, az öncélúságánál fogva céltalan teljesítmény és a végeérhetetlenség jellemzi a liquid modernity korát (Baudrillard 1997: 43). Ahogy Baumannál a zsákmány megszerzését felváltja a zsákmány hajszolása, úgy Baudrillard-nál a múködés helyébe a múködtetés lép, az eredetileg célorientált cselekedet öncélúvá, az eredetileg külsô objektumra irányuló cselekedet önmagára irányulva önmagát objektiválja. Bauman értelmezését követve ennek okát abban találhatjuk meg, hogy a cselekvések kiinduló- és végpontját, motivációt és célt a stabil struktúrák és intézmények tudnak meghatározni, ezek jelölik ki a társadalmi és egyéni cselekvések és értelmezések hosszú távon is érvényes keretrendszerét. A liquid modernity fázisában éppen ez a stabilitás tûnik el, a struktúrák nem elég tartósak ahhoz, hogy hosszú távú viszonyulásokat, magatartási mintázatokat, tartós referenciával bíró narratívákat jelölhessenek ki. A narratívák érvényüket vesztik, távlatok hiányában az idố a pillanatok sorozatára szúkül, az új célok megtalálásának és megszerzésének szekvenciái széttörik az idô folyamatosságát, amelynek végtelensége a pillanatokban rejlô kiaknázatlan lehetôségek végtelen sorozataként jelentkezik (Bauman 2007: 32). A konform magatartássá ezzel a rugalmasság válik, a pillanatokban rejlô lehetôségek kibontása, folyamatos igazodás a körülményekhez, a múlékony és változékony célok követésének és feladásának ritmustalan váltakozása. A fogyasztásnak e fogyasztásában a felesleg (excess) már nem irracionális, céltalan, de a liquid modernity köztességében a lehetôségek kibontásának nélkülözhetetlen kerete, biztosítéka és bizonyítéka, maga a norma (Bauman 2001: 131-133.).

Más fogalmi keretben, de hasonló jelenséget rögzít az idố tapasztalatának átalakulásával összefüggésben Szakolczai Árpád (Szakolczai 2016) ${ }^{[4]}$ és Bjorn Thomassen (Thomassen 2014), amikor - részben Victor Turnert kritizálva - korunkat a permanens liminalitás fogalmán keresztül írják le. Az átmeneti rítusok Arnold van Gennep által adott modelljének (Gennep 2007) középsô, átmeneti szakaszára utalva a szerzôk amellett érvelnek, hogy a tekintélyek hiányában eltûnnek azok a szereplők, akik autentikus módon ki tudnák jelölni, hogy az átmenetiségnek honnan hová kellene vezetnie, az egyénnek az átmenetiség után mivé kellene válnia. Vagyis amíg a premodern átmeneti rítusok minden esetben struktúrákat kötöttek össze, a különböző strukturális állapotok között vertek hidat, az új struktúrákba való beilleszkedést, az új szerepkészletek egyéni elsajátítását, a megváltozott státusz társadalmi elfogadtatását garantálták, addig korunkban a beavatott szereplôk, az értékelések és keretek hiányában az egyénnek tulajdonképpen nincs hová eljutnia. Pontosabban az egyénbe zárt célok képtelenek túlmutatni egyszeri, zárt érvényú, s éppen ezért instabilnak bizonyuló vonatkozásaikon (vö. Bauman 1991: 237), míg társadalmi szinten a 
beavatottságot mímelő, de a hosszabb távon érvényes irányokat nem ismerô trickster figurák érvényesülnek. A liquid modernity fázisában a struktúrák hiányában tehát csak átmeneti helyzetek váltják egymást, az identitást nem társadalmi keretek jelölik ki, megtalálása egyéni projektté, elvégzendô feladattá, életen át tartó kemény munkává válik (Bauman 1992b: 166-167.), amelynek teljesítéséhez a piac a „csináld magad” szellemében fogant eszközök sorozatát termeli ki (Bauman 2007: 110-111.).

A pillanatok kapocs nélküli monádjaiba zárt egyéni életút tehát nem átíveli és összeköti a töréseket, hanem törések sorozatába ágyazódik. Az identitásnak tehát mindig rugalmasnak és változékonynak kell maradnia (Bauman 2007: 49), az identitás keresése jelentkezik életfeladatként (vö. Erôs 1998: 147). Az identitás folyamatos mozgása, aktuális identitások kialakítása a múlt lezárásának állandó lehetôségét, az újrakezdések és újraszületések végtelen sorozatát ígérik (Bauman 2007: 100-101.). A struktúrák helyét átvevô ürességben (void) a kísérletezés könnyú, nincsen, ami akadályt gördíthetne elé, de eredményei sosem stabilak, életciklusuk rövid, így sosem képesek az ígért egzisztenciális biztonságot megteremteni (Bauman 2001: 99).

Visszatérve a játék értelmezéséhez, kiindulhatunk abból, hogy a program folyamatosan változó keretrendszert jelent. Azok a stratégiák, szerepek, eszközök, amelyek tegnap még hatékonynak bizonyultak és sikeressé tették az egyént, holnapra elavulttá válnak. A program tehát egy olyan közeget teremt, amelyben folyamatos mozgás van, az egyéntôl folyamatos alkalmazkodást követel meg, már ha továbbra is sikeres kíván maradni, meg akarja ôrizni a felhasználók között elfoglalt társadalmi pozícióját, amely nagyrészt e sikerességen nyugszik. A közegben azonban ennek az alkalmazkodásnak nincsen semmiféle akadálya, gyakorlatilag csak a ráfordított idô és az esetleges külsô tôkebevonás (úgynevezett token vásárlása és átváltása a játékon belüli fizetôeszközre) függvénye. A felhasználói fiókok tulajdonosai ugyanis több karaktert tarthatnak fenn, fejleszthetnek és alakíthatnak, ahogy a meglévô karakterek is mindig újragondolhatóak. Ami azonban az újrakezdések, a végtelen életek megélésének privilégiuma, az egyszerre kötelesség is (vö. Bauman 2007: 100), a program változó keretrendszeréhez megfelelố alkalmazkodás. 
A változás azonban nem írható le kizárólag a megszakítottságon keresztül, ugyanilyen fontos része a haladás képzete is. A program egy olyan környezetet teremt meg, ahol folyamatosan nô a megszerezhetô eszközök ereje, hatékonysága. A megszakítás, a korábban felvett szerepek,eszközök stb. megváltoztatásának körkörössége a számszerúen kifejezhetô növekedés linearitásába ágyazódik. Az adaptálódás tehát a domináns használati módban központi szerepet betöltố haladás, a fejlôdés, az elôrejutás (progress) eszköze. A program tehát a folyamatos változások mellett a fejlôdés, erôsödés pontokban kifejezhetô rendszerével orientációs pontot teremt az egyénszámára. A túltermelt információk korában az információval túlterhelt egyének számára éppenezek a narratívák, rendek és fejlődési periódusok hiányoznak (Bauman 2007: 41). A külsô referenciarendszer, a célt és az irányt meghatározó narratívával - a fent leírt kitérôk és vakvágányok ellenére - a használatot kumulatív folyamatként képes láttatni, az egyéni fejlôdés képzetét megteremtve, a használat a változékony önmeghatározás eszközébôl egyfajta életcéllá nôhet ki (vö. Bauman 1992a: 194).

A program azonban ezt az ígéretet nem feltétlen képes beváltani. A felhasználó ugyanis egy ponton célba ér, legyôzi a narratívába beemelt legfóbb ellenségeket, s mondhatnánk, ezzel véget ér a program, az egyén eljut valahová. A program azonban nem ér véget, egyfelól azért, mert mindennapos múködése - bár hasonlóan célorientált, de - független a narratíva logikájától, másfelôl azért, mert új kiegészítôk jelennek meg, amelyek sok esetben éppen a korábbi narratívát, célokat írják radikálisan felül. A program használatából tehát hiányoznak a végpontok, az elkezdés és a befejezés, a belépés és a kilépés az esetleges egyéni döntésen túlmutató határai. Ha a játékok, ahogy azt Huizinga nyomán megfogalmazhatjuk, sok esetben ünnepi keretbe ágyazódó, liminális cselekmények, akkor jól látható, hogy folyamatosságával és a célok sorozatosságával ez a program valójában a permanens liminalitás állapotát teremti meg (vö. Myers 2009: 59). Az ígéretek ellenére ugyanis az egyénnek nincsen honnan hová eljutnia, a kijelölt célok üresnek bizonyulnak, s egyáltalán, a programnak nincsen vége. A program forgalmazói trickster figuraként a célokat folyamatosan változtatva, a fejlôdés szintjeit folytatólagosan kitolva nem elvezetik valahova az egyént, hanem a program használata jelentette liminális helyzetet teszik állandóvá.

A permanens liminalitásban ugyanis nem maguk a célok számolódnak fel, hanem a céloknak stabilitást, tartós értéket biztosító társadalmi struktúrák. A premodern liminális helyzetekkel szemben a permanens liminalitás állapotában a célok illékonnyá, esetlegessé válnak és végsô soron kiüresednek; egyfelôl adott a beavatást szolgáló, különbözô státuszba bevezetô rituális póznaugrás, másfelôl a bungee jumping, az ugrás önmagáért való élménye (Thomassen 2014). A gyakorlatban és a program szúkebb kontextusában az adatközlők többsége az adott kiegészítô feladatainak teljesítése után, a narratívába ágyazódó cselekedetek elvégzését követôen sem hagyott fel a használattal, tovább halmozott tárgyakat, teljesített kisebb feladatokat. A különbözô lépések ugyanis látszólagos tárgyorientáláságuk ellenére cselekvésorientáltak; az újra és újra, más-más tárggyal kapcsolatban aktualizálódó vágyakból, a sorozatosan megújuló és irányt váltó célokból a biztos pontokat áhító ember számára mint e különbözô célok közös nevezóje a vágy marad fenn állandóként; a programban nem a beérkezés, hanem a mozgásban maradás a cselekmények célja. 
Ahogy Baudrillard is megfogalmazza, a múködés helyébe, amelynek a cél adott értelmet, a csak önmagában értelmezhetô, önmaga által legitimált múködtetés lép, amelyet „a kiválóság, az erőfeszítés, a rekord és a gyerekes önfelülmúlás sportteljesítményt értékelô együtthatójával mérünk" (Baudrillard 1997: 13).

Azonban nemcsak a felhasználó, hanem maga a program is folyamatos mozgásban van. A megváltozott körülmények mindig új feladatokat jelölnek ki. Teljesítésüknek és megszerzésüknek, a hírek és változások követésének, az elônyösnek bizonyuló szerepek felvételének, a hatékony stratégiák adaptálásának sikeressége a folyamatos készenlét és cselekvés függvénye. Az ebbool származó feszültség, energiabefektetés képes kitölteni minden ürességet, benyomulni az ürességben megszólaló végsố kérdések helyére, amelyek a gondtalan fogyasztást megzavarhatnák (Bauman 2007: 95). Valóban túlságosan derúlátónak tûnik tehát Victor Turner, amikor azt reméli, hogy a posztmodern közegben a liminoid állapotok az egzisztenciális kérdések közegévé válnak, $\mathrm{s}$ helyesebbnek tûnik Szakolczai és Thomassen diagnózisa, akik a konyhakész, rendelésre fogyasztható átmeneteket a minden végsô kérdést elfedô limivoid fogalmával írták le (Szakolczai 2016; Thomassen 2014).

A haladás feladatok, felmutatható teljesítmények, birtokba vett eszközök formájában, javuló statisztikai adatokban a program által az egyén felé, az egyén által mások felé kommunikálható. Sốt, a legtöbb esetben az egyéni szándékoktól függetlenül is kommunikált formában van jelen. Más cselekvésekhez hasonlóan, ahol szintén lehet egyfajta értékmérô az ügyesség és a tudás, a használatban való jártasság (skill) ebben a közegben is nemcsak nyilvános, de számszerúsíthetô, összemérhető, felmutatható. A birtokolt eszközök, a teljesített feladatok és a megszerzett képességek legfontosabb köre tehát mások számára is látható, a program közegében értelmezhetô jel. Mint ilyenek az egyénrôl mint a program használójáról alakítanak ki képet mások és önmaga számára. A különböző eszközök és teljesítmények tehát többek mint immateriális tárgyak vagy elvégzett feladatok, más értékmérôk híján az önfelmutatás szinte kizárólagos eszközei. Láthatóságuk által tehát ezek a jelként funkcionáló képességek és tárgyak a tömeges követés által autoritásra tesznek szert, az egyéni életút célját és irányát elôre meghatározó minták helyét betöltve az önmeghatározás eszközeivé, orientációs pontokká válhatnak (vö. Bauman 1992a: 195).

Természetesen az eszközök csak korlátozott számban mutathatók fel, ahogy például a felhasználó neve mögé illeszthetô, különbözô feladatok elvégzésérôl tanúskodó címek közül is egyszerre csak egy jelenhet meg. Az aktuálisan használt és a potenciálisan használható, korábban összegyújtött eszközök aránya a használattal párhuzamosan egyre nô. ${ }^{[5]}$ Így például a különbözô hátasokból ( mount) adatközlőimnek általában több száz volt a birtokában. 


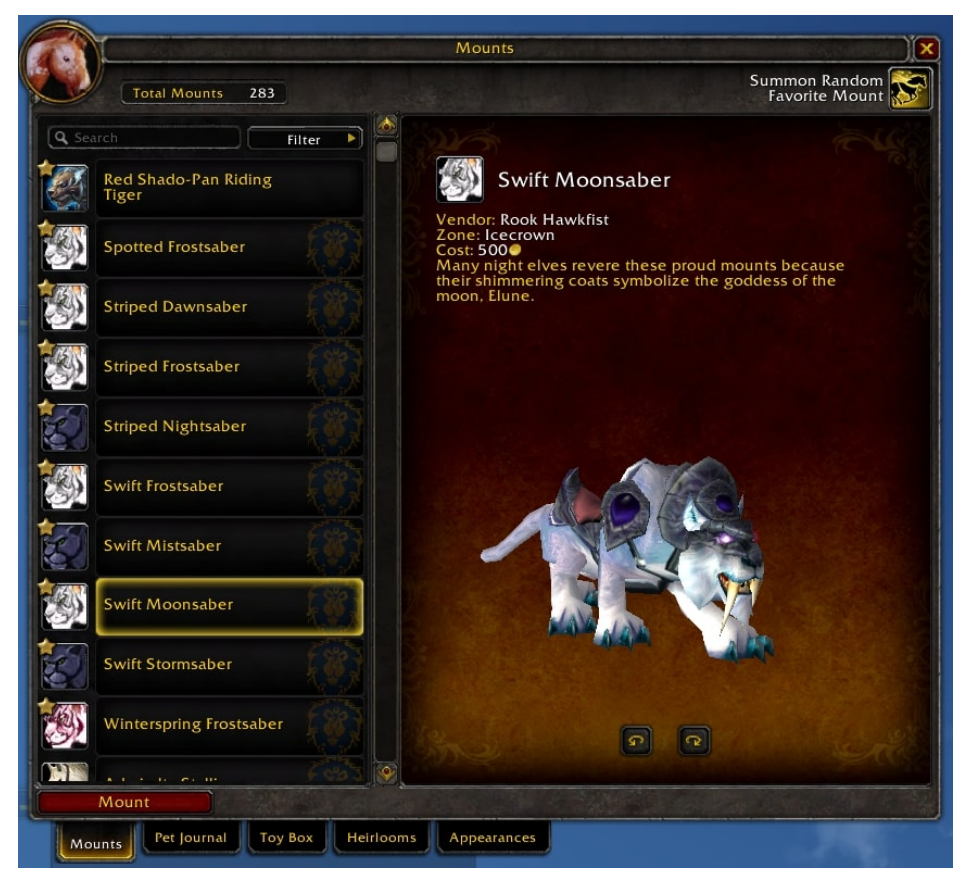

Az egyik adatközlö hátasainak tára

Értelemszerúen ezek közül egyszerre legfeljebb egyet lehet használni, a mozgást elôsegítô funkciójukban pedig alapvetôen csak a repülés képességének tekintetében különböznek. Így bár a megszerzésük fáradtságba és idôbe kerül, túlnyomórészt csak küllemükben különböznek A célracionalitás szempontjából ezek gyưjtése felesleges, ahogy összességükben az elôzô bekezdésben tárgyaltak értelmében sem lehet ezeket az önfelmutatás eszközeként használni. Közvetetten, mint kommunikációs üzeneteknek szerepük lehet az önfelmutatásban, ugyanis a felhasználók közötti beszélgetéseknek gyakori témája lehet, hogy kinek hány darab áll birtokában az adott típusból, vagy hogy egy konkrét, ritka, nehezen fellelhetô darabot megszerzett-e már. A jelfunkcióhoz képest azonban ezen szerepük csak másodlagos, ahogy hatásukat tekintve, az üzenet befogadóinak számára nézve is csekélyebb a hatásuk. Tehát mind a szigorúan vett racionalitás, mind az önfelmutatás szempontjából csak a legerôsebb, legújabb, legnehezebben megszerezhetô eszközöknek, teljesítményeknek van szó szoros értelemben vett használati értéke, a többi felesleges. Ahogy azt fentebb általánosan, úgy most a program konkrét esetében is megállapíthatjuk azonban, hogy a felesleg ténylegesen normává válik, azaz a program használatával mindenki fölöslegessé vált dolgokat halmoz fel. A tárgyak, eszközök jelentôs hányadának gyưjtése, felhalmozása korántsem szükségszerú, mégis általánosan elterjedt. Ugyanis míg külső, racionális szempontból ez fölöslegesnek tûnhet, addig a permanens liminalitás állapotában a fölösleg nem haszontalan, hanem éppen az utak keresésének megkerülhetetlen eszköze és velejárója (vö. Bauman 2001: 133).

A célracionalitás szempontjából szintén érthetetlen az a rengeteg erôfeszítés, amit a felhasználók a karakterek küllemének kialakítására fordítanak. Legyenek öltözetek, eszközök vagy hátasok, a hatékonyság mellett a legfontosabb érv mellettük az, hogy az egyén szemében tetszetôsek. A két elv fontosságát mi sem mutatja jobban, mint hogy a hatékonyság és az egyéni ízlés kibékítésére külön funkciót hoztak létre, amely lehetôvé teszi, hogy a kevésbé hatékony, de máskülönben 
vonzó tárgy egyéb hatékonyabb tárgyak tulajdonságait vehesse át (transmog).

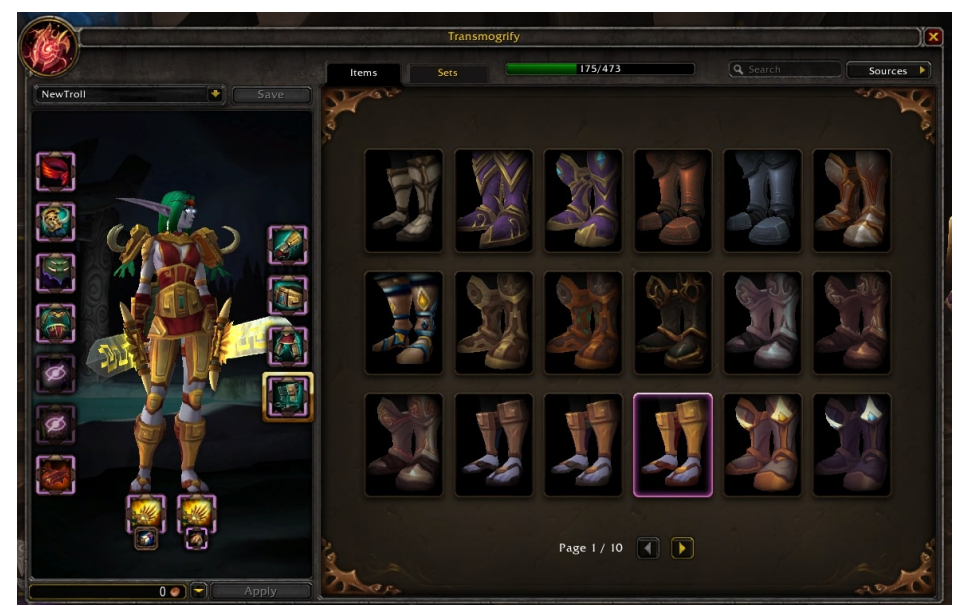

Az öltözet és fegyverzet küllemének megváltoztatását szolgáló felület.

A képen látható, hogy különbözö cipókböl az adatközlömnek százhetvenöt darab volt a birtokában.

Mindez az esetek többségében rengeteg erőfeszítést és idôt követel meg, amit a célracionalitás felól hiába is próbálnánk értelmezni. A külsô kialakításának szentelt figyelmet a test fontossága felől érthetjük meg. Ehhez egyfelől el kell fogadnunk, hogy a számítógép képernyőjén megjelenô karakter teste hasonló funkciót tölt be, mint az egyén fizikai teste: a változások közepette biztos pont, a folyamatos mozgásban lévő identitáshoz mérten orientációs pont, kommunikációs felület az egyén és a külvilág között (vö. Bauman 1992a: 194). Másfelól az ízlés ethosza - az vagy, ami tetszik - ebben a közegben is eluralkodik (Bauman 2001: 52).

A test kérdése átvezet minket a program azon sajátosságához, hogy virtualitása elfedi materialitását. A materiális javak - így például a programon belüli különbözô játékszerek (toys) immateriálisa azonban nemhogy megkérdôjelezné, de tökéletesíti a materiális javak cirkulálásán alapuló önidentifikációs folyamatokat. Ugyanis minden korábban megszerzett dolog, ami még tegnap önmagunk megteremtésének eszköze volt, az másnapra önmagunk megteremtésének a gátjává válik: ballaszt, ami a fogyasztót akadályozza a mozgásban (Bauman 2007: 84-87.). A javak immaterialitása tehát leveszi a felhasználó válláról a fölöslegtôl való megszabadulás nehézkes és sokszor költséges, a beszerzésnél mindenesetre bajosabb terhét. 


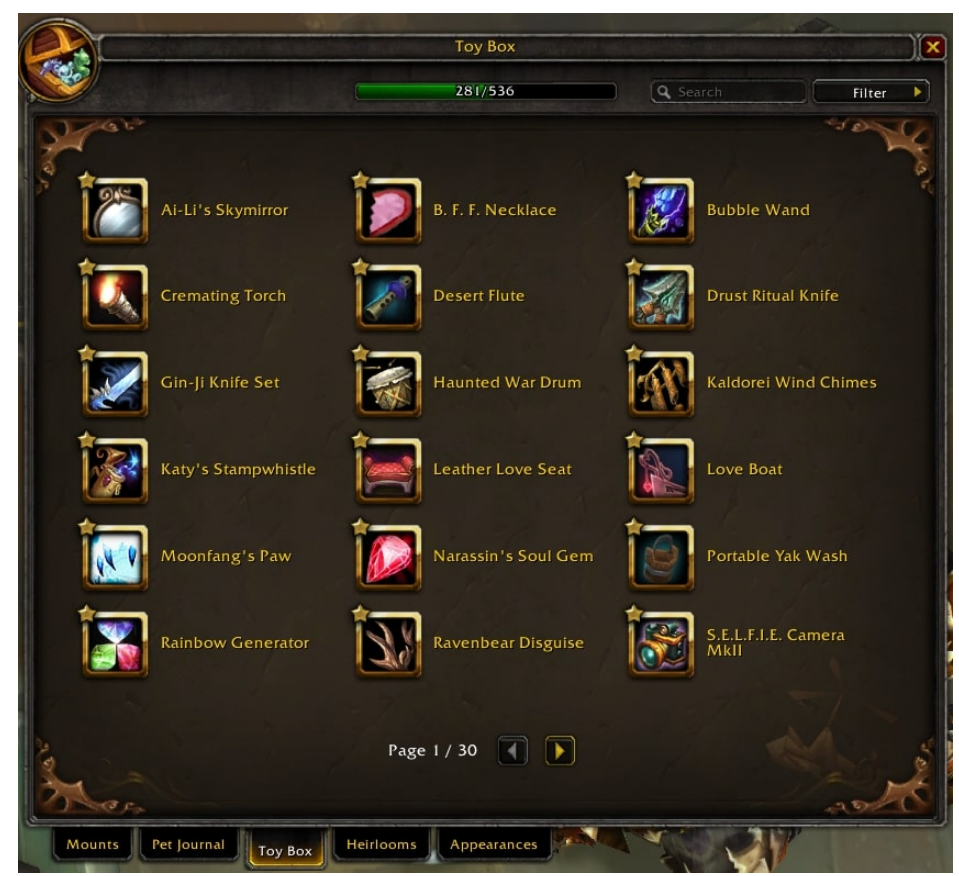

Gondtalan felhalmozás. A játékszerek azon dolgok körébe tartoznak, melyeknek tárolása teljesen problémamentes a programban.

Végül még nem ejtettünk szót a játékon belül kialakult csoportokról. Hajlamosak vagyunk ezeket a csoportokat közösségnek hívni, sôt, egyes játékokkal foglalkozó tudományos szövegek már nemcsak egy-egy játék, hanem egy játéktípus teljes fogyasztói körére közösségként utalnak (vö. Harper 2014). A közösség fogalma minden bizonnyal egyike a homályosan, rendkívül vitatottan meghatározott, mégis kulcsfontosságú társadalomtudományi fogalmaknak (vö. Tóth 2002). Minden eltérô értelmezés ellenére is bizonyos azonban, hogy több millió tagot számláló, egymást nem ismerô, sôt, egymásról mit sem sejtô, a világ legkülönbözőbb pontjain élố emberek körét nem lehet közösségként leírni. Vagyis a közösség esetében hasonló folyamatot regisztrálhatunk, mint a játék esetében: a forgalmazók által vonzó címkeként használt fogalmakat reflektálatlanul megfeleltetik a társadalomtudományi terminusnak. Mindenesetre, ha ezzel könnyen el is vethetjük azt a képtelenséget, hogy a program felhasználóinak teljes körére közösségként tekintsünk, még mindig nem foglalkoztunk a formálisan is létezô, egymást általában valóban ismerô személyekből álló kisebb csoportokkal. Általános megítélésük nehézkesnek tûnhet, hiszen létszámukat, múködésmódjukat, a személyek közötti kapcsolatok milyenségét, a tagok közötti kommunikáció gyakoriságát és tartalmát tekintve e csoportok rendkívül változatosak. $\mathrm{E}$ különbségek ellenére mégis találhatunk egy közös pontot, miszerint a közösség a csoportok esetében nem állapot, hanem cél. A közösség nem az egyén természetes közege, hanem egy vágyott társas állapot. A premodern közösségekkel szemben e csoportok nem a vágyott egzisztenciális biztonságot hozzák el, hanem a szorongás további forrásává válnak, nincsen közös valóságuk, csak e közös valóság egyéni képzete (Bauman 1992a: 198-199.). A közösségek ugyanis nem töltenek be védelmező funkciót, amelyek az egyéni hibák következményeitôl védenék meg az egyént (vö. Bauman 2001: 17), ehelyett az egyéni hibák lecsapódásának elsôdleges közegévé válnak: a társas közeg, amelyben a szabályok bármikor megváltozhatnak nem egyesíti, hanem 
elválasztja az embereket (Bauman 2001: 48). A gyakorlatban ez azt jelenti, hogy a teljesítményében visszaesô, az új szabályokhoz, mechanizmusokhoz alkalmazkodni képtelen egyént nem vonják be - a fejlődésben kiemelkedô szerepet betöltô - közös feladatok végrehajtásába, ezáltal teljesítménye még inkább elmarad a többiekétôl, a csoporton belül marginalizálódik. Mindez személyes konfliktusokat generál és végül a tag kilépéséhez vezethet. A csoport tehát általában nem garanciákat biztosít, hanem a teljesítményt fokozó nyomást fejt ki.

A programon belül kialakult, általam megismert csoport elsődleges referenciapontja, a tagok közötti kapcsolat alapja maga a program. Ez még azokban az esetekben is igaznak bizonyult, amikor a kapcsolatok elmélyültek, és a tagok között tartós barátságok szövődtek. A csoportképződés alapja tehát mindvégig az a tágan vett esztétikai tapasztalat maradt, amit a program használataként írhatunk le (vö. Myers 2009). Mindez beilleszthetố abba a tágabb tendenciába, melyet Bauman a csoportszerveződéssel kapcsolatban jelez: a közösségek mély beágyazottsága, a társas élmények, megnyilvánulások és tevékenységek széles körét átfogó volta átalakul, leszúkül, s általában pusztán egyetlen közös esztétikai tapasztalat köré szervezôdik (vö. Bauman 2001: 66). Az esztétikai közösségben való tagság fontosságra, az esztétikai élmény közösségformáló erôre azáltal tehet szert, hogy az egyéni ízlés a liquid modernity fázisában meghatározó identitást formáló elemként van jelen (Bauman 2007: 70).

A közösségre a program forgalmazóinak és felhasználóinak ugyanazon célból van szüksége: a közösség a cselekvéseknek egyik kitüntetett értelemadó közege (vö. Bauman 2001: 36). Vagyis ahogy fentebb láttuk, a narratíva mint értelmezési keret valójában hamar kiüresedik. A haladás számokban kifejezhetô értéke a növekedéssel ugyan kontinuus, de mint abszolút érték messze nem olyan hatékony, mint relatív mérôszám. Azaz a játék pontokban kifejezhetô rendszerében összehasonlíthatóvá tesz teljesítményeket, az önmagában csak önmagunkhoz mérhető eredményeket másokra vonatkoztathatóan az önpozicionálás és önmeghatározás eszközévé teszi.

Összességében tehát a program egy olyan közeget hoz létre, amelyben a folyamatosan jelentkező új célok, új megszerezhetô dolgok újonnan születô vágyak tárgyaivá és az önidentifikáció eszközeivé válhatnak. Közegében nincsen véglegesség, minden újrakezdhetô és újra kezdendô, folyamatos a megérkezés nélküli mozgás. Társas közege az eredmények összemérési felülete, az identitás mozgóképének önmagában is mozgó projekciós felülete. A folyamatos mozgás, újdonságok, a szüntelen cselekedetek és törekvések minden ürességet betöltenek, amelyet a használat végső értelmének kérdése felvethetne.

Kiinduló kérdésünkre visszatérve megállapíthatjuk, hogy a játék fogalma vagy a játék és a munka szembeállítása nem is feltétlen alkalmatlan, mint inkább irreleváns kerete a program értelmezésének. Huizinga klasszikusára visszatérve, a definíciótól továbbvezethet korának a játékkultúráról adott értelmezése.

Ha pedig meg akarjuk állapítani a mai társadalmi élet játéktartalmát (a politikai életet beleértve), akkor világosan látjuk, hogy két eset lehetséges: vagy többé-kevésbé tudatosan 
alkalmazzák a játékformákat, hogy a politika vagy társadalom valamiféle célját takarják ezzel. Ebben az esetben nem a kultúra örök játékelemeivel van dolgunk, amelyet ebben a könyvben kimutatni igyekeztünk, hanem hamisjátékkal - de az is lehetséges, hogy már elsô felületes pillantásra olyan jelenségekre bukkanunk, amelyek látszólag játékszerúek és így félrevezetnek bennünket. A mai közösség hétköznapját fokozódó mértékben jellemzi egy olyan tulajdonság, amelynek egyes vonásai közösek a játékéval és amelyben talán egyesek a modern kultúra gazdag játéktartalmát vélik felfedezni. Ezt a tulajdonságot legtalálóbban puerilizmusnak nevezzük, olyan kifejezéssel, amely a pubertás elôtti fejlődési szakaszban illik az emberre, tehát a gyermetegség és az ifjúkori kiegyensúlyozatlanság közti állapotot fejezi ki. (Huizinga 1944: 214-215.)

Szembeszökő, hogy a kötet lendülete a szöveg végén megtörik, a szerzô a kortárs kultúra talaján már kevésbé magabiztosan mozog. Ítéleteinek bizonytalanságát betudhatjuk múvelôdéstörténeti érdeklôdésének, annak, hogy a jelen kevésbé ismerôs terep számára. Mégis úgy gondolom, hogy ez nem kellóen kielégítô magyarázat, és árulkodóbb, hogy maga Huizinga is kilép a korábban alkalmazott fogalmi keretból. Bevezeti a puerilizmus fogalmát, amellyel éppen a korábban végigvezetett játék és komolyság dichotómiáját függeszti fel. Ha tekintetbe vesszük, hogy a puerilizmus szemében - többek között - a „soha ki nem elégített, habár olyan könnyen kielégíthetố banális szórakozások utáni vágy” (Huizinga 1944: 215) vagy a „minden olyan illúzió iránti fogékonyság, amely a hiúságnak és a csoporttudatnak hízeleg” (Huizinga 1944: 215), akkor egyértemúvé válik, hogy nagyon hasonló jelenséget ért a fogalom alatt, amelyet általánosságban és a program használatával kapcsolatban megpróbáltam felvázolni.

Ilyenkor bukkan fel a kérdés, amely számunkra fontos: vajon a mai társadalom gazdagon virágzó puerilizmusát játékfunkciónak lehet-e nevezni, vagy nem? Elsố pillantásra úgy tûnik, hogy csakis igennel lehet erre felelni; magam is így interpretáltam ezt a jelenséget korábbi, a játék és kultúra viszonyáról szóló elmélkedéseimben. De most azt hiszem, élesebben kell megvonnom a játékfogalom meghatározásának határait és ezért kizárom a puerilizmust ebból a fogalomkörból. A játszó gyermek nem gyermekes. Csak akkor válik azzá, ha a játék untatja, vagy ha nem tudja, hogy mit játsszon. Ha a mai általános puerilizmus igazi játék volna, akkor ezzel a társadalom visszatért volna az archaikus kultúrformákhoz, amelyekben a játék eleven kultúrteremtô tényezô volt. Talán sokan hajlandók lesznek a közösség fokozódó „rekrutálódásában” ennek a fordulatnak elsô állomását látni. Mi úgy hisszük, hogy nincs igazuk. Minden olyan jelenségben, amelyben a szellem önként mond le nagykorúságáról csak a közeli bomlás tüneteit észlelhetjük. Az igazi játék ismertetô jelei hiányzanak belóle, még ha a puerilis viselkedés sokszor fel is veszi a játék formáit. Hogy ismét áhítatot, stílust és méltóságot kapjon, ahhoz más utakra kell térnie a kultúrának. (Huizinga 1944: 216-217.)

A puerilizmus tehát nem játék, ahogy a gamification sem a játékok reneszánsza, hanem a Huizinga által felvázolt út új mérföldköve, mely oda vezet, hogy „a modern kultúrát már alig játsszák, és 
ahol úgy látszik, mintha mégis ezt tennék, ott hamisjátékról van szó” (Huizinga 1944: 217). A játékok címkéje alatt, a permanens liminalitás állapotában felbukkanó trickster jellegú figurák által kínált termékek így sok esetben csak utánozzák a játékok mechanizmusait, miközben tartalmukat kiüresítik. A program profitorientált forgalmazói kihasználják a struktúrák és a közösségek hiányában identitásukban elbizonytalanodott emberek éhségét az értelmes cselekvésekre. Az elvégzendố feladatokkal a haladás illúzióját teremtik meg, de a beérkezés helyett csak a fokozható teljesítmény és a halmozható javak logikája által diktált folyamatos mozgást kínálják követôik számára. Az egzisztenciális alászállások és felemelkedések tartalma helyett a horizontális távlatok végtelennek tetsző formáit kínálják fel. Olyan rendszert hoznak létre, amelyben a tartalomra való tekintet nélkül az egyén önmagát ellenôrzi, fegyelmezi, motiválja, melyben általános egzisztenciális helyzete érdektelen és értelmezhetetlen, miközben az elôtte álló feladat, a másokhoz mért teljesítménye önmeghatározásának, társas megítélésének fokmérôje. Míg tehát a program szerepjátékot, felfedezést, kilépést ígér, addig a társadalmi elôrejutásnak a fogyasztáson és a termeléson nyugvó világába vezet be (Rettberg 2008). A program virtuális, látszólag idegen és távoli közege tehát nem más, mint a liquid modernity korszakának a materialitás terhétôl megszabadított - ennél se nem jobb, se nem rosszabb, bár környezetileg talán kevésbé káros egyik tere. A kapitalista gazdasági rendszertôl nem feltétlen idegenkedô kritikusai így sokszor nem is mechanizmusai, hanem eredményeinek, javainak elzártsága miatt emelnek szót (vö. Dreyfus 2009; Potter 2015). Nem csoda, hogy napjainkban rengeteg erôfeszítést tesznek azért, hogy a hasonló programok rendkívül hatékonynak bizonyuló mechanizmusait a gamifikáció jegyében becsatornázzák a fősodorba, s általában a termelés maximalizálásának eszközeként használják (Jagoda 2013). És ez már nem játék.

\section{Jegyzetek}

1. A hazai szakirodalomban, illetve Baumann magyarra fordított írásaiban a terminussal cseppfolyós és folyékony modernitásként egyaránt találkozhatunk. Mivel a hazai szakirodalomban a fordítással kapcsolatban még nem alakult ki konszenzus, ezért a következókben a kifejezést eredeti formájában használom.

2. A kutatás pontosabb módszertani, a csoport részletesebb etnográfiai bemutatását lásd Bakos 2015.

3. Elterjedt megnevezés még a klán (clan). Az általam vizsgált csoport tagjai általában a guild szót használták, a következôkben ennek magyar fordítását használom.

4. Fôbb téziseinek magyar nyelven közreadott vázlatát lásd Szakolczai 2015.

5. A tanulmányban nem tárgyalom a programban gyújthetô, felhalmozható dolgok teljes körét, mivel ezek áttekintése az érvelést alapvetôen nem módosítaná, ellenben a program világában járatlan olvasók számára a szöveg befogadását valószínúleg megnehezítené.

\section{Irodalomjegyzék}

- Bakos Áron (2015): Játék a játékon túl: Beszámoló egy online közösségrôl szóló kutatás eredményeiról. Antroport Lapozó, 10.

- Bakos Áron (2016): Karnevál a hálón: trollkodás egy sok játékos részvételén alapuló online 
szerepjáték világában. Erdélyi Múzeum, 78. 2. 153-165.

- Baudrillard, Jean (1997): A rossz transzparenciája. Ford. Klimó Ágnes. Budapest, Balassi-BAE Tartóshullám-Intermedia.

- Bauman, Zygmunt (1992a): Intimations of Postmodernity. London-New York, Routledge.

- Bauman, Zygmunt (1992b): Mortality, Immortality and Other Life Strategies. Cambridge, Polity.

- Bauman, Zygmunt (1993): Modernity and Ambivalence. Cambridge, Polity.

- Bauman, Zygmunt (2000): Liquid Modernity. Cambridge-Malden, MA, Polity.

- Bauman, Zygmunt (2001): Community. Seeking Safety in an Insecure World. Cambridge-Malden, MA Polity.

- Bauman, Zygmunt (2007): Consuming Life. Cambridge-Malden, MA, Polity.

- Baym, Nancy K. (2006): Interpersonal Life Online. In The Handbook of New Media. Szerk. Leah A. Lievrouw-Sonia Livingstone. London-Thousand Oaks-New Delhi, Sage, 35-54.

- Clayre, Alasdair (1974): Work and Play. London, Widenfeld and Nicolson.

- Dreyfus, Hubert L. (2009): On the Internet. London-New York, Routledge.

- Erôs Ferenc (1998): A (zsidó) identitás labirintusai. In Élettörténet és megismerés. Tanulmányok Pataki Ferenc tiszteletére. Szerk. Csepeli György-Kovács Zoltán-László János. Budapest, Scientia Humana, 143-151.

- Gennep, Arnold van (2007): Átmeneti rítusok. Ford. Vargyas Zoltán. Budapest, MTA Néprajzi Kutatóintézet-PTE Néprajz - Kulturális Antropológia Tanszék.

- Harper, Todd (2014): The Culture of Digital Fighting Games. Performance and Practice. New York-London, Routledge.

- Hine, Christine (2015) Ethnography for the Internet. Embedded, Embodied and Everyday. London, Bloomsbury.

- Huizinga, Johan (1944): Homo Ludens. Ford. Máthé Klára. Budapest, Athenaeum.

- Jagoda, Patrick (2013): Gamification and Other Forms of Play. boundary 2, 40. 2. 113-144. https://doi.org/10.1215/01903659-2151821

- Mauss, Marcel (1966): The Gift. Forms and Function of Exchange in Archaic Societies. London, Cohen \& West.

- Myers, David (2009): The Video Game Aesthetic. Play as Form. In The Video Game Theory Reader 2. Szerk. Bernard Perron-Mark J. P. Wolf. New York-London, Routledge, 45-63.

- Paoli, Stefano De (2013): Automatic-Play and Player Deskilling in MMORPGs. Game Studies, 13. 1.

- Potter, W. James (2015): Médiamúveltség. Ford. Kató Eszter. Budapest, Wolters Kluwer.

- Rettberg, Scott (2008): Corporate Ideology in World of Warcraft. Digital Culture, Play, and Identity. A World of Warcraft Reader. Szerk. Hilde G. Corneliussen-Jill Walker Rettburg. Cambridge, MA, The MIT Press, 19-38.

- Szakolczai Árpád (2015): Marginalitás és liminalitás. Státuszon kívüli helyzetek és átértékelésük. Regio, 23. 2. 6-29. https://doi.org/10.17355/rkkpt.v23i2.66

- Szakolczai Árpád (2016): Permanent Liminality and Modernity. Analysing the Sacrificial Carnival Through Novels. London, Routledge. https://doi.org/10.4324/9781315600055

- Taneli, Tolga-Guo, Yu-Heng-Mushtaq, Sabina (2015): Viselkedésfüggóségek. Ford. Váradi Enikő-Budai Katalin. Budapest, Oriold. 
- Thomassen, Bjørn (2014): Liminality and the Modern. Living through the In-Between. Farnham-Vermont, Ashgate.

- Tóth G. Péter (2002): A „közösség”: egy fogalom megalkotása, kiteljesedése, széthullása és felszámolása. Közösség és identitás. Szerk. Pócs Éva. Budapest-Pécs, L’Harmattan-PTE Néprajzi Tanszék, 9-31.

- Turner, Edith (2012): Communitas. The Anthropology of Collective Joy. New York, Palgrave Macmillan.

- Turner, Victor (1974): Liminal to Liminoid, in Play, Flow, and Ritual: An Essay in Comparative Symbology. Rice Institute Pamphlet Rice University Studies, 60. 53-92.

- Wacquant, Loïc (2009): Punishing the Poor. The neoliberal government of social insecurity. Durham-London, Duke University Press.

https://doi.org/10.1215/9780822392255 
(C) Apertúra, 2019. tél | www.apertura.hu webcím: https://www.apertura.hu/2019/tel/bakos-fogyasztas-liminalitas-puerilizmus-egysokresztvevos-online-szerepjatek-hasznalatarol/

https://doi.org/10.31176/apertura.2019.14.2.5

$$
\text { (2) opertúro }
$$

